\title{
ANALYSIS READINESS OF SOUTH KALIMANTAN SWIMMING ATHLETES IN THE FACE OF NATIONAL CHAMPIONSHIPS
}

\author{
Lazuardy Akbar Fauzan', Edwin Wahyu Dirgantoro², Ihip ${ }^{3}$, \\ Sofia Monalisa ${ }^{4}$, Muhammad Fauzi Rahman ${ }^{5}$ \\ Universitas Lambung Mangkurat ${ }^{1,2,3,4,5}$ \\ Lazuardy.fauzan@ulm.ac.id
}

\begin{abstract}
Athlete achievement can be measured from the readiness of physical, technical, mental, and strategic aspects. Swimming is a prestigious sport so its achievements are highly expected. The purpose of this research is to know the readiness of swimming athletes pengprov PRSI South Kalimantan in participating in the national championship. This study is a descriptive quantative study. The population in this study was a national swimming athlete pengprov South Kalimantan which amounted to 17 people. The sampling technique used is total sampling. The data analysis technique used is descriptive statistical analysis. Based on the results of research analysis of physical readiness and engineering, South Kalimantan athletes obtained excellent results. But there are only 2 and 3 athletes who fall into the national category.
\end{abstract}

Keywords: Analysis, Swimming, National

Accepted: $25^{\text {th }}$ of January 2022

Correspondence author: Lazuardy Akbar Fauzan, Universitas Lambung Mangkurat, Indonesia. E-Mail: Lazuardy.fauzan@ulm.ac.id

DOI http://dx.doi.org/10.31851/hon.v5i1.6473

(c) (i) (2)

Jurnal Halaman Olahraga Nusantara licensed under a Creative Commons Attribution-ShareAlike 4.0 International License

\section{INTRODUCTION}

The expected achievement targets will be achieved if athletes and coaches carry out good training. Aspects of training that need to be prepared in training include physical, technical, mental, and strategic aspects (Syafruddin, 2011) (Ucup Yusup, Bambang Erawan, 2017) (Wibowo \& Rahayu, 2016). The physical aspect is a basic compound for athletes to prepare physically in accordance with the norms of the athlete level. Physical condition plays an important role especially in improving the function and system of the body's organisms (soegiyanto, 2011). physical is one of the conditions yang used in achieving an achievement (Nur \&Hidayah, 2017).

The technical aspect is an exercise to get the effectiveness and efficiency of movement in accordance with their respective sports. Mastery of basic techniques 
is very important because it relates to the automaticity of motion and the effectiveness of movement. Athletes can master the basic techniques of continuous technical training by doing repetitions (Fadly Hidayat, 2019). Good technical mastery must be mastered by every athlete, because the technical aspect is an internal factor of an athlete that can affect sports achievement (Haryanto et al., 2021). Lack of movement skills or techniques in a sport can affect the achievement of athletes (Rido Pratama, 2019).

The results of research from (Enggar Yudha Cahyandaru, 2015) good physical ability can improve the achievement of swimming style, it can be known by a significant relationship between speed and swimming achievement. Research from (Arif et al., 2019) states that in a swimmer hope to maximize thrust and minimize the force of drag to move faster (Toussaint \& Beek, 1992). This push style is the result of the efforts of swimming players to move the hands, hips, and legs so that they can move forward (Scurati et al., 2019). This movement technique is very influential on the time record of a swimmer (Ferreira \&Arbosa, 2016).

The mental aspect is the readiness of metal to compete and the mental fighting power of athletes in achieving the achievement targets that have been set. Mental is basically related to thoughts and thought processes involving emotional and intellectual (Adi, 2016). (Smith et al., 2016) said that "Mental fatigue impairs soccer-specific running, passing, and shooting performance". Based on the explanation that athletes who have a bad mentality will affect their performance when competing on the field. The strategy aspect is a strategy to put yourself in the number (part) of the championship that is expected to achieve maximum achievement. Strategy is a strategy designed before the game takes place and used by players and coaches to achieve victory (Permatasari, 2020). Coaching strategies carried out by coaches through communication patterns, family, and organizational support contribute to success to improve the achievements of fostered athletes (Muslima \& Himam, 2018). These four aspects are things that 
must be prepared properly before determining the expected achievement targets in all participation of athletes at all levels of the championship. Research from (Imansari et al., 2015) athlete coaching strategies obtained from swot analysis results there are four, namely utilizing the conformity of vision and mission with current coaching conditions as a foundation in conducting early age coaching, improving athlete welfare by utilizing stakeholder commitment, improving the quality and quantity of human resources by utilizing competition methods and stable political conditions, and improve the quality of sports facilities and infrastructure that are in accordance with standards by utilizing cooperation with third parties.

Based on the results of the National Student Sports Week (POMNAS) swimming championship in 2019 held in DKI Jakarta, the South Kalimantan swimming contingent did not get a medal (AntaraNews, 2019). Pon XIX West Java 2016 results, South Kalimantan swimming contingent did not get a medal (Rappler, 2016). From this there is an inequality between the existing potential and the resulting performance.

National level championship is a routine championship that is held within a certain period of time. Each region is given the opportunity to participate in the championship. National championship has a high prestige value if athletes can get a champion. Conversely, if you do not excel at the national level, athletes and coaches can be said to fail in terms of coaching. In the near future, PON and other national championships will be implemented soon. Athletes and coaches began preparing for the championships. Therefore, this study deserves to be carried out to analyze the readiness of athletes in participating in national level championships.

Prsi swimming athletes are the best athletes from various city districts in South Kalimantan Province. Athletes who pass the selection are then given coaching, trained and given an exercise program. The athlete represented South Kalimantan Province in participating in the championship at the national and even international level. Each specific period, the KALSEL PRSI Projecter conducts an 
evaluation of the training process. Athletes who do not achieve their next expectations will be sidelined and can be replaced by athletes who are more potential in achieving.

South Kalimantan PRSI producers have a target of obtaining aquatic achievements at the national level. This is in accordance with what was conveyed by the Chairman of the South Kalimantan PRSI Provincial Government Hj Hariyati in an interview on Radar Banjarmasin Wednesday, January 2, 2019. In order to realize these targets, revamping and evaluating exercises continues to be carried out. One of the policies implemented is to collaborate with the Department of Sports Education FKIP ULM in terms of research and development of swimming sports achievement.

From the above explanation, the author wants to see the readiness of swimming athletes prsi kalsel pengprov reviewed from the aspects of physics and engineering. Physical and technical aspects are very influential on the achievements that will be targeted by the coach. This physical and technical aspect is also a basic aspect or initial aspect that needs to be prepared early on. By knowing the level of readiness of physical aspects and techniques possessed by athletes, then the plateh can determine the program drill mental and apply strategies that are in accordance with theathlete's condition.

This research offers a novelty that is by analyzing the readiness of physical and technical aspects of South Kalimantan swimming athletes. Previous research that has been conducted only focuses on coaching the sport of swimming in South Kalimantan (Nurdiansyah, 2014). Therefore, this study aims to find out the level of readiness of physical aspects and technical aspects by conducting a more indepth analysis. This research can later contribute to the coaching of swimming sports in the South and can be an informational literature for coaches, organizational administrators and lecturers about swimming sports coaching. 
Jendral A. Yani Street Lorong Gotong Royong 9/10 Ulu Palembang South Sumatera

email jurnal: jurnalhon@univpgri-palembang.ac.id situs web: http://www.univpgri-palembang.ac.id

\section{Accredited}

SINTA 3

\section{METHOD}

This study is a descriptive quantative study. Quantative research aims to find or obtain something unknown such as knowing the results of analysis of potential athletes in South Kalimantan reviewed from the aspect of readiness of physical and technical aspects. The methods used in this study are fitness practice tests to determine the level of readiness in the physical aspect and the practice test mastery of basic swimming techniques with the best time recording to find out the level of readiness in the technical aspect.

The population in this study was the national level swimming athlete pengprov South Kalimantan. The sample in this study was all national level swimming athletes pengprov South Kalimantan which amounted to 17 people. The sampling technique used is total sampling.

Research instruments are tools selected and used by researchers in their activities to collect so that the activity becomes systematic and facilitated by him (Arikunto, 2016). The research instruments used in this study are: 1) Observation, and 2)Tests and measurements of physical and engineering aspects. The movement component that will be observed and assessed consists of 6 components of swimming technique movement which includes the start phase, body phase when gliding, arm movement phase, limb movement phase, breath taking phase, coordination phase.

The data analysis used in this study is statistical analysis and nonstatistic analysis. In this study, a researcher was able to use one of these analyses because the data collected in the form of numbers, then the author used statistical analysis. In accordance with the opinion of Sutrisno Hadi (Sutrisno Hadi, 2000) who said scientific ways that are prepared to collect data by analyzing the data that is in the form of numbers are technical statistics. The data analysis in this study used SPSS 20. 


\section{OLATRAGA

\section{RESULT AND DISCUSSION}

In this study the authors took data on aspects of engineering using observations. The observations were made by two observers. Each observer assesses the results of observations of athletes' swimming movement techniques using observation sheets that have been provided. The values of the 2 observation officers are then accumulated and then the data is published. Based on the analysis of engineering aspect data obtained the following data.

Table 1. Butterfly-styles wimming pool

\begin{tabular}{ccrl}
\hline Class intervals & \multicolumn{2}{c}{ Frequency } & \multirow{2}{*}{ Category } \\
Value & Absolute & Relative & \\
\hline $121-150$ & 9 & $53 \%$ & Excellent \\
$91-120$ & 8 & $47 \%$ & good \\
$61-90$ & 0 & $0 \%$ & \\
$31-90$ & 0 & $0 \%$ & \\
$<31$ & 0 & $0 \%$ & \\
\hline
\end{tabular}

Based on the table above it can be seen that the swimming ability of butterfly style as many as 9 people (53\%) fall into the category of very good and as many as 8 people (47\%) fall into the good category.

Table 2. freestyle swimming

\begin{tabular}{ccrl}
\hline Class intervals & \multicolumn{2}{c}{ Frequency } & \multirow{2}{*}{ Category } \\
Value & Absolute & Relative & \\
\hline $121-150$ & 17 & $100 \%$ & Excellent \\
$91-120$ & 0 & $0 \%$ & \\
$61-90$ & 0 & $0 \%$ & \\
$31-90$ & 0 & $0 \%$ & \\
$<31$ & 0 & $0 \%$ & \\
\hline
\end{tabular}

Based on the table above it can be seen that the ability of freestyle swimming as many as 17 people (100\%) fall into the category is very good or it can be concluded that all athletes have excellent freestyle swimming ability. 
Table 3. Swimming backstroke

\begin{tabular}{ccrl}
\hline Class intervals & \multicolumn{2}{c}{ Frequency } & \multirow{2}{*}{ Category } \\
Value & Absolute & Relative & \\
\hline $121-150$ & 12 & $71 \%$ & Excellent \\
$91-120$ & 5 & $29 \%$ & good \\
$61-90$ & 0 & $0 \%$ & \\
$31-90$ & 0 & $0 \%$ & \\
$<31$ & 0 & $0 \%$ & \\
\hline
\end{tabular}

Based on the table above it can be seen that the ability to swim backstroke as many as 12 people (71\%) fall into the category of excellent and as many as 5 people (29\%) fall into the good category.

Table 4. Kability to swim breaststroke

\begin{tabular}{ccrl}
\hline Class intervals & \multicolumn{2}{c}{ Frequency } & \multirow{2}{*}{ Category } \\
Value & Absolute & Relative & \\
\hline $121-150$ & 13 & $87 \%$ & Excellent \\
$91-120$ & 4 & $13 \%$ & good \\
$61-90$ & 0 & $0 \%$ & \\
$31-90$ & 0 & $0 \%$ & \\
$<31$ & 0 & $0 \%$ & \\
\hline
\end{tabular}

Based on the table above it can be seen that the breaststroke swimming ability of 13 people (87\%) falls into the category of excellent and as many as 4 people (13\%)fall into the good category.

On the engineering aspect, the authors took the data using a physical test. The physical test components used are flexibility, muscle strength, muscle endurance, power, and $\mathrm{VO}_{2}$ Max. From the results of the physical test then dianalis data.

Swimming is a measured sports group. Measured sports are sports whose results are seen from their mileage or the results can be seen directly and accurately (Adzilika, 2018). Swimming uses a measure of time to see its achievements. Each style in swimming and every swimming championship has its own time limit. The 


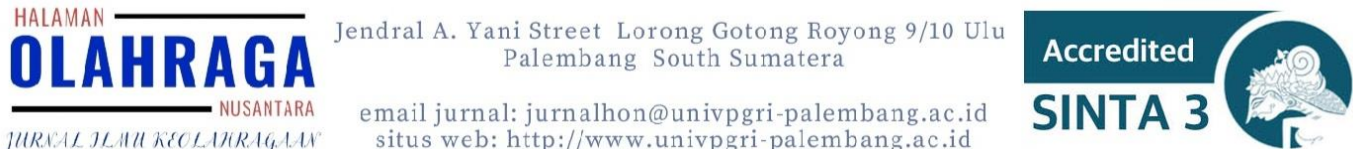

time limit is used as a reference or limit in measuring the extent of the readiness of athletes in participating in the championship.

\section{Discussion}

Based on the results of the analysis of the readiness data of technical aspects and physical aspects of south Kalimantan swimming athletes can be concluded that athletes have had good technical and physical readiness, there are even some who fall into the category of verygood. This is in accordance with what was conveyed by Syafruddin (2011) that the physical condition and technique is the basisfor developing achievement, if the physical condition berada at a low level if to apply the technique effectively and efficiently can not be done. Althoughthe mastery of breaststroke swimming techniques is very good, but not supported by excellent physical condition, the pretense can not be achieved optimally (Haryanto et al., 2021).

Swimming is included in the sport of measured (Ruslan Abdul Gani,2020). This measurable sport can be directly observed the results achieved by athletes. In swimming, which is used as a measure of an athlete's success, the time record obtained by the athlete in each style is recorded in seconds to second. Each swimming time gain is called best time. Athletes in have goodswimming achievements if the time record is shorter / faster than the time of achievement (Erisetyawan et al., 2016). In each championship there is also a record time. The time record in a championship is called the time limit. This time limit is used to select athletes who will participate in the championship. If the athlete has a time limit that is short of the championship time limit then the athlete can participate in the championship.

The readiness of a swimming athlete is determined by the speed of a swimming athlete to get the shortest time. In swimming, speed is the most important component because speed is needed when competing to achieve maximum performance (Shava et al., 2017). Atlet is required to enter within the 
predetermined championship time limit. Other factors that affect the readiness of swimming athletes in the championship are physical and technical readiness. If the results of physical tests and techniques of an athlete are good but the best time does not enter the time limit of the championship then the athlete can certainly not participate in the championship.

In south Kalimantan swimming athletes it can be observed that there are 2 athletes who enter the time limit of the national swimming championship breaststroke 50 meters and butterfly style 50 meters. And as many as 3 athletes fall into the time limit category of the national swimming championship in the 50 meters backstroke and in the 50 meters freestyle. The entry of the time limit of the athlete is not a guarantee that the athlete can get a champion. The time limit is only limited to the entry of these athletes to participate in the national championship. To get the champion, you must pay attention to the opponent who is his rival in the championship. The more prestigious a championship, the tighter the best time swimming athletes earn.

Based on the results of analysis of physical and technical readiness data, South Kalimantan athletes obtained excellent results, but in terms of best time there are still many who lag behind the national championship limit. It can be analyzed that in the sport of swimming, good physical ability is very influential on a person's swimming ability. The authors observed the results of an analysis of athlete data that entered the time limit of national swimming championships are athletes who have a record of physical tests that fall into the category is very good. This is in accordance with (Haryanto et al., 2021) that the element of physical condition provides the ability for an athlete's body to produce good and correct techniques effectively and efficiently.

\section{CONCLUSION}

Based on the results of research analysis of physical readiness and engineering, South Kalimantan athletes obtained excellent results. But there are only 2 and 3 athletes who fall into the national category. This can be seen from the 
Analysis Readiness of South Kalimantan Swimming Athletes in The Face of National

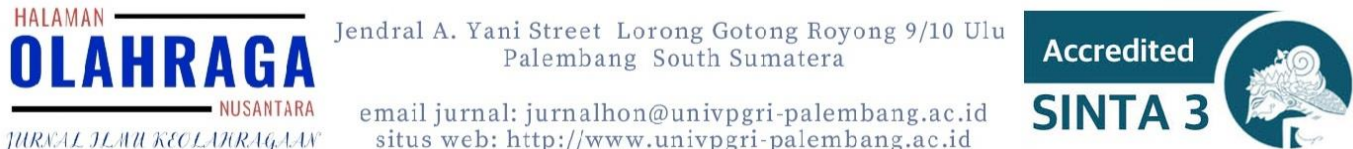

butterfly style swimming as many as9 people (53\%) fall into the category of very good and as many as 8 people (47\%) fall into the good category. The ability of freestyle swimming as many as 17 people (100\%) falls into the category of very good or it can be concluded that all athletes have excellent freestyle swimming ability. The ability to swim backstroke as many as 12 people (71\%) fall into the category of very good and as many as 5 people (29\%) fall into the good category. 13 breaststroke swimming skills (87\%) fall into the category of very good and as many as 4 people (13\%) fall into the good category. The physical ability of athletes as many as 11 people fall into the category of very good and as many as 6 people fall into the good category. Based on the results of these data, the readiness of the physical aspects of swimming athletes is very good. The time limit of the national swimming championship as many as 2 athletes fall into the category of time limit of the national swimming championship in the 50 meters breaststroke and in the 50 meters butterfly style. And as many as 3 athletes fall into the time limit category of the national swimming championship in the 50 meters backstroke and in the 50 meters freestyle.

To the coaches and stakeholders in order to be able to be the results of this study as information and evaluation materials to improve the readiness of South Kalimantan swimming athletes both in number and quality of athletes in participating in national swimming championships.

\section{REFERENCES}

Adi, S. (2016). Latihan Mental Atlet Dalam Mencapai Prestasi Olahraga Secara Maksimal. Prosiding Seminar Nasional, 1-11.

Adzilika, A. (2018). Evaluasi Program Pembinaan Prestasi Atlet Cabang Olahraga Terukur Di Provinsi Lampung. Jurnal Of Physical Education And Sport, 8(1), $56-61$.

Antaranews. (2019). Dki Jakarta Borong Emas Pada Cabor Renang Pomnas 2019. In News Report (Issue September). Https://Www.Antaranews.Com/ Berita/1077690/DKI-Jakarta-Borong-Emas-Pada-Cabor-Renang-Pomnas2019

Arif, M., Ardha, A., Yang, C. B., Ridwan, M., \& Darmawan, G. (2019). Analisis 
Lazuardy Akbar Fauzan, Edwin Wahyu Dirgantoro, Ihip, Sofia Monalisa, Muhammad Fauzi Rahman, (2022)

Analysis Readiness of South Kalimantan Swimming Athletes in The Face of National Championships

Jendral A. Yani Street Lorong Gotong Royong 9/10 Ulu Palembang South Sumatera

email jurnal: jurnalhon@univpgri-palembang.ac.id situs web: http://www.univpgri-palembang.ac.id

\section{Accredited}

SINTA 3

Biomekanika Pada Stroke Nomor 100 Meter Gaya Dada Terhadap Swimming Velocity. 9.

Arikunto, S. (2016). Manajemen Penelitian. Pt. Rineka Cipta.

Enggar Yudha Cahyandaru. (2015). Hubungan Antara Kecepatan, Kelentukan Dan

Daya Tahan Vo2 Max Terhadap Prestasi Renang Gaya Bebas 50 Meter Di

Pusat Pembinaan Atlet Berbakat (PAB) Daerah Istimewa Yogyakarta

[Universitas Negeri Yogyakarta]. Skripsi (Issue 4).

Https://Eprints.Uny.Ac.Id/18625/1/Skripsi.Pdf

Erisetyawan, A., Mulyana, D., \& Hidayah, N. (2016). Efektivitas Software Swim

Race System Terhadap Penempatan Nomor, Seri, Dan Lintasan Dalam

Perlombaan Renang. Jurnal Kepelatihan Olahraga, 8(1), 21-35.

Fadly Hidayat, M. S. R. (2019). Pengaruh Latihan Drill Terhadap Peningkatan

Kemampuan Passing Bawah Pemain Bolavoli. Tjyybjb.Ac.Cn, 3(2), 58-66.

Http://Www.Tjyybjb.Ac.Cn/Cn/Article/Downloadarticlefile.Do?Attachtype= Pdf $\& I d=9987$

Ferreira, M. A. I. F., \& Arbosa, T. I. M. B. (2016). Energetics,Biomechanics, And Performance In Masters 'swimmers:Asystematic Review Maria. 30(7).

Haryanto, J., Wijaya, A. S., Skevio, W. M., \& Okilanda, A. (2021). Analisis Keterampilan Teknik Renang Gaya Dada Atlet Renang Golden Black Swimming Club Kota Padang. 7(2), 380-391.

Imansari, A. T., Dwimawanti, I. H., \& Santoso, R. S. (2015). Analisis Strategi Pembinaan Atlet Oleh Dinas Kebudayaan Pariwisata Pemuda Dan Olahraga Kabupaten Pati. Journal Of Public Policy And Management Review, 4(2), 111.

Muslima, T. F., \& Himam, F. (2018). Peran Pelatih Dalam Pembinaan Prestasi Atlet

Pada Organisasi Taekwondo Profesional. Gadjah Mada Journal Of Professional Psychology (Gamajpp), 2(3), 186. Https://Doi.Org/10.22146/ Gamajpp.41769

Nur, M., \& Hidayah, T. (2017). Pengaruh Metode Latihan Dan Power Otot Tungkai Terhadap Kelincahan. Journal Of Physical Education And Sports, 6(3), 279285.

Nurdiansyah. (2014). Evaluasi Pembinaan Olahraga Renang Di Provinsi Kalimantan Selatan Banjarmasin. Jurnal Multilateral, Volume 13, No. 2 Desember 2014, 13(2), 150-165.

Permatasari, D. (2020). Latihan Di Kabupaten Bantul Saat Pandemi Covid-19 Tahun 2020. In Skripsi Fakultas Ilmu Keolahragaan Universitas Negeri Yogyakarta. 
Rappler. (2016). Hasil Cabang Olahraga Renang Pon Xix Jabar 2016. Https://Www.Rappler.Com/World/Hasil-Medali-Renang-Pon-Xix-Jabar2016

Rido Pratama, M. (2019). Analisis Keterampilan Gerak Renang Gaya Dada Pada Atlet Renang. Jurnal Patriot, 2(3), 376-381.

Scurati, R., Gatta, G., Michielon, G., \& Cortesi, M. (2019). Techniques And Considerations For Monitoring Swimmers' Passive Drag. Journal Of Sports Sciences, 37(10), 1168-1180. Https://Doi.Org/10.1080/02640414.2018. 1547099

Shava, I., Kusuma, D. W. Y., \& Rustiadi, T. (2017). Latihan Plyometrics Dan Panjang Tungkai Terhadap Kecepatan Renang Gaya Dada Atlet Renang Sumatera Selatan. Physical Education And Sports, 6(3), 266-271.

Smith, M. R., Coutts, A. J., Merlini, M., Deprez, D., Lenoir, M., \& Marcora, S. M. (2016). Mental Fatigue Impairs Soccer-Specific Physical And Technical Performance. Medicine And Science In Sports And Exercise, 48(2), 267-276. Https://Doi.Org/10.1249/Mss.0000000000000762

Soegiyanto. (2011). Kondisi Atlet Panahan Program Atlet Andalan Nasional Indonesia Emas (Prima). Media Ilmu Keolahragaan Indonesia, 1(1). Https://Doi.Org/10.15294/Miki.V1i1.1132

Sutrisno Hadi. (2000). Methodology Research (2nd Ed.). Yayasan Penerbitan Fakultas Psikologi UGM.

Syafruddin, 2011. (2011). Ilmu Kepelatihan Olahraga (1st Ed.). UNP Press.

Toussaint, H. M., \& Beek, P. J. (1992). Biomechanics Of Competitive Front Crawl Swimming. Sports Medicine: An International Journal Of Applied Medicine And Science In Sport And Exercise, 13(1), 8-24. Https://Doi.Org/10.2165/00007256-199213010-00002

Ucup Yusup, Bambang Erawan, Dan E. H. (2017). Hubungan Kondisi Fisik, Tingkat Kesehatan, Psikologis Dengan Prestasi Atlet Cabang Olahraga Beladiri Jawa Barat Di Pon Xix 2016. Jurnal Kepelatihan Olahraga, 10(2), 74-84.

Wibowo, S. A. P., \& Rahayu, N. I. (2016). Pengaruh Latihan Mental Imagery Terhadap Hasil Tembakan Atlet Menembak Rifle Jawa Barat. Jurnal Terapan Ilmu Keolahragaan, 1(2), 23. Https://Doi.Org/10.17509/Jtikor. V1i2.2776 